\title{
Allylic cross-coupling using aromatic aldehydes as $\alpha$-alkoxyalkyl anions
}

\author{
Akihiro Yuasa, Kazunori Nagao and Hirohisa Ohmiya*
}

\author{
Letter \\ Address: \\ Division of Pharmaceutical Sciences, Graduate School of Medical \\ Sciences, Kanazawa University, Kakuma-machi, Kanazawa \\ 920-1192, Japan \\ Email: \\ Hirohisa Ohmiya* - ohmiya@p.kanazawa-u.ac.jp \\ * Corresponding author \\ Keywords: \\ aldehyde; copper; copper catalysis; cross-coupling; palladium; \\ synthetic method
}

\author{
Beilstein J. Org. Chem. 2020, 16, 185-189. \\ doi:10.3762/bjoc. 16.21 \\ Received: 15 October 2019 \\ Accepted: 03 February 2020 \\ Published: 07 February 2020 \\ This article is part of the thematic issue "Copper-catalyzed reactions for \\ organic synthesis". \\ Guest Editor: O. Riant \\ (C) 2020 Yuasa et al.; licensee Beilstein-Institut. \\ License and terms: see end of document.
}

\begin{abstract}
The allylic cross-coupling using aromatic aldehydes as $\alpha$-alkoxyalkyl anions is described. The synergistic palladium/copper-catalyzed reaction of aromatic aldehydes, allylic carbonates, and a silylboronate produces the corresponding homoallylic alcohol derivatives. This process involves the catalytic formation of a nucleophilic $\alpha$-silyloxybenzylcopper(I) species and the subsequent palladium-catalyzed allylic substitution.
\end{abstract}

\section{Introduction}

$\alpha$-Alkoxy-substituted carbanions ( $\alpha$-alkoxyalkyl anions) are useful $\mathrm{C}\left(\mathrm{sp}^{3}\right)$ nucleophiles for the construction of alcohol units found in a majority of pharmaceuticals, agrochemicals and bioactive natural products. Generally, $\alpha$-alkoxyalkyl anions are presynthesized as stoichiometric organometallic reagents such as organolithium, organozinc, organocuprate, organostannane, organosilane and organoboron compounds [1-6]. Alternatively, we showed that easily available aromatic aldehydes can be used as $\alpha$-alkoxyalkyl anions for catalytic carbon-carbon bond formations [7-9]. For example, a nucleophilic $\alpha$-silyloxybenzylcopper(I) species can be generated catalytically from aromatic aldehydes through the 1,2-addition of a silylcopper(I) species followed by [1,2]-Brook rearrangement and then successfully trapped with aryl bromides under palladium catalysis (Scheme 1). This system was extended to an asymmetric version using the chiral $\alpha$-silyloxybenzylcopper(I) species having a chiral NHC ligand. In the asymmetric system, one example of allylic carbonate was used as the carbon electrophile $[8,10,11]$. This paper describes in full detail the racemic system using allylic carbonates. The allylic cross-coupling of aromatic aldehydes and allylic carbonates with a silylboronate by the merging of a copper- $N$-heterocyclic carbene catalyst and a palladium-bisphosphine catalyst produced homoallylic alcohol derivatives [12-14]. 


Scheme 1: Our strategy.

\section{Results and Discussion}

Specifically, the three-component allylic cross-coupling reaction of benzaldehyde (1a, $0.4 \mathrm{mmol})$, tert-butyl cinnamyl carbonate (2a, $0.2 \mathrm{mmol})$ and (dimethylphenylsilyl)boronic acid pinacol ester $\left[\mathrm{PhMe}_{2} \mathrm{SiB}(\mathrm{pin})\right](0.4 \mathrm{mmol})$ occurred in the presence of catalytic amounts of $\mathrm{Pd}\left(\mathrm{OCOCF}_{3}\right)_{2}(3 \mathrm{~mol} \%)$, DPPF (3 mol \%), (SIPr)CuCl (15 mol \%) and $\mathrm{KO} t$ - $\mathrm{Bu}$ (25 mol \%) in toluene at $80{ }^{\circ} \mathrm{C}$ to afford homoallylic alcohol derivative 3aa in $64 \%$ yield (based on 2a) (Scheme 2). The reaction yielded small amounts of side products such as cinnamylsilane and benzyl silyl ether, which are derived from the Pd-catalyzed allylic silylation of $\mathbf{2 a}$ and the $\mathrm{Cu}$-catalyzed silylation of 1a and the subsequent [1,2]-Brook rearrangement, respectively. In this coupling reaction, $(\mathrm{SIPr}) \mathrm{CuCl}$ was a slightly better copper complex than (IPr)CuCl $(62 \%)$, (SIMes) $\mathrm{CuCl}(60 \%)$ and (IMes) $\mathrm{CuCl}(53 \%)$ in terms of the chemical yield. Notably, the allylic cross-coupling reaction did not occur at all without $\mathrm{Pd}\left(\mathrm{OCOCF}_{3}\right)_{2}-\mathrm{DPPF}$ or $(\mathrm{SIPr}) \mathrm{CuCl}$, and thus the palladium and copper catalysts cooperatively acted in the allylic cross-coupling.

Scheme 3 shows the substrate range of aromatic aldehydes $\mathbf{1}$ and allylic carbonates 2 . Methyl, tert-butyl and fluoro substituents were tolerated at the ortho- or para-positions of the aromatic aldehyde (3ba-da). 2,6-Dimethylphenyl- or 1-naphthyl moieties as the $\gamma$-substituent of the primary allylic carbonate were tolerated in the reaction (3ab and 3ac). Cinnamyl carbonates having a fluoro or acetal substituent were also suitable coupling partners (3ad and 3ae).
The synergistic palladium/copper catalysis was used for the reaction of a secondary allylic carbonate. For example, the allylic cross-coupling of $\mathbf{2} \mathbf{a}$ ', a constitutional isomer of $\mathbf{2 a}$, with benzaldehyde (1a) afforded the linear allylation product $\mathbf{3 a a}$ with complete regioselectivity. The symmetric secondary allylic carbonate was converted to the corresponding homoallylic alcohol derivative in $50 \%$ yield (3af).

To gain understanding into the mechanism of this synergistic palladium/copper-catalyzed allylic cross-coupling, a stoichiometric experiment was conducted (Scheme 4). The reaction of the SIPr-ligated $\alpha$-silyloxybenzylcopper 4 with the cinnamyl-palladium complex $\mathbf{5}$, which was prepared in situ from [(cinnamyl)PdCl $]_{2}$ and DPPF, gave the corresponding homoallylic alcohol derivative 3aa.

Based on previous reports and the outcome obtained by the stoichiometric experiment in Scheme 4, a possible reaction pathway involving a cooperative action of palladium and copper catalysis can be proposed as illustrated in Scheme 5 . The reaction of SIPr-ligated $\mathrm{CuCl}(\mathbf{A}), \mathrm{KO} t$ - $\mathrm{Bu}$ and a silylboronate produces a silylcopper(I) species $\mathbf{B}$. The 1,2-addition of silylcopper(I) $\mathbf{B}$ to the aromatic aldehyde $\mathbf{1}$ [15-19] and the subsequent [1,2]-Brook rearrangement from the obtained $\alpha$-silyl-substituted copper(I) alkoxide $\mathbf{C}$ forms the key intermediate, an $\alpha$-silyloxybenzylcopper(I) species D. The transmetallation between $\mathbf{D}$ and an allylpalladium(II) species $\mathbf{F}$ that is generated through the oxidative addition of an allylic carbonate 2 across a palladium(0)-DPPF complex $\mathbf{E}$, followed by

\footnotetext{
Scheme 2: Allylic cross-coupling using aldehydes as $\alpha$-alkoxyalkyl anions.
} 


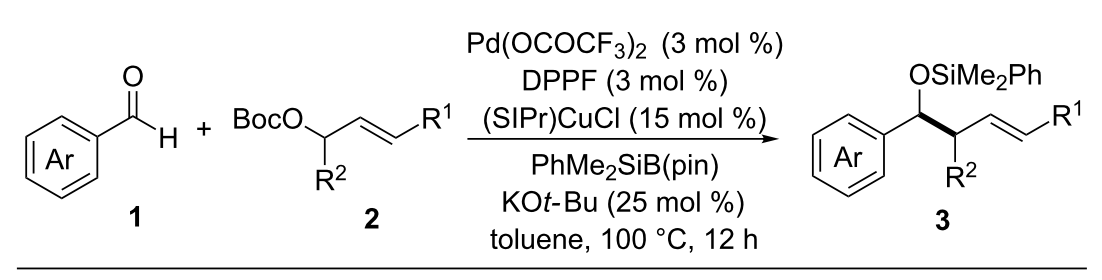<smiles>COc1ccccc1C(C/C=C/c1ccccc1)OC</smiles>

3ba, $44 \%^{\text {b }}$<smiles>COC(C/C=C/c1ccccc1)c1ccc(C(C)(C)C)cc1</smiles>

3ca, $49 \%^{\text {c }}$<smiles>COC(C/C=C/c1ccccc1)c1ccc(F)cc1</smiles>

3da, $62 \%^{\mathrm{d}}$<smiles>Cc1cccc([N+](=O)[O-])c1/C=C/CC(O[Na])c1ccccc1</smiles>

3ab, $49 \%$<smiles>COC(C/C=C/c1cccc2ccccc12)C(c1ccccc1)c1ccccc1</smiles><smiles>OCC(CC=Cc1ccccc1F)c1ccccc1</smiles>

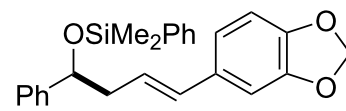

3ae, $36 \%$ 3ad, $48 \%$<smiles>CCOC(C/C=C/c1ccccc1)C/C=C/C(OC(C)(C)C)c1ccccc1</smiles>

3aa, 39\%<smiles>COC(c1ccccc1)C(/C=C/c1ccccc1)c1ccccc1</smiles>

3af, $50 \%(\mathrm{dr} 1: 1)^{\mathrm{e}}$

Scheme 3: Substrate scope and reaction conditions. a) reactions were carried out with $1(0.4 \mathrm{mmol}), 2(0.2 \mathrm{mmol}), \mathrm{PhMe}_{2} \mathrm{SiBpin}(0.4 \mathrm{mmol})$ $\mathrm{Pd}\left(\mathrm{OCOCF}_{3}\right)_{2}(3 \mathrm{~mol} \%)$, DPPF (3 mol \%), (SIPr)CuCl $(15 \mathrm{~mol} \%)$, KOt-Bu $(25 \mathrm{~mol} \%)$ in toluene $(2 \mathrm{~mL})$ at $100{ }^{\circ} \mathrm{C}$ for $12 \mathrm{~h}$. b) Pd(OCOCF $)_{2} / \mathrm{DPPF}^{\circ}$ $(3 \mathrm{~mol} \%),(\mathrm{SIPr}) \mathrm{CuCl}(25 \mathrm{~mol} \%)$ and $\mathrm{KOt}-\mathrm{Bu}(35 \mathrm{~mol} \%)$ were used and the reaction temperature was decreased to $\left.80^{\circ} \mathrm{C} . \mathrm{c}\right) \mathrm{Pd}\left(\mathrm{OCOCF}_{3}\right)_{2} / \mathrm{DPPF}$ $(3 \mathrm{~mol} \%),(\mathrm{SIPr}) \mathrm{CuCl}(25 \mathrm{~mol} \%)$ and $\mathrm{KOt}-\mathrm{Bu}(35 \mathrm{~mol} \%)$ were used. d) The reaction temperature was decreased to $80{ }^{\circ} \mathrm{C}$. e) $\mathrm{Pd}\left(\mathrm{OCOCF}_{3}\right)_{2} / \mathrm{DPPF}$ $(5 \mathrm{~mol} \%),(\mathrm{SIPr}) \mathrm{CuCl}(25 \mathrm{~mol} \%)$ and $\mathrm{KOt}-\mathrm{Bu}(35 \mathrm{~mol} \%)$ were used.

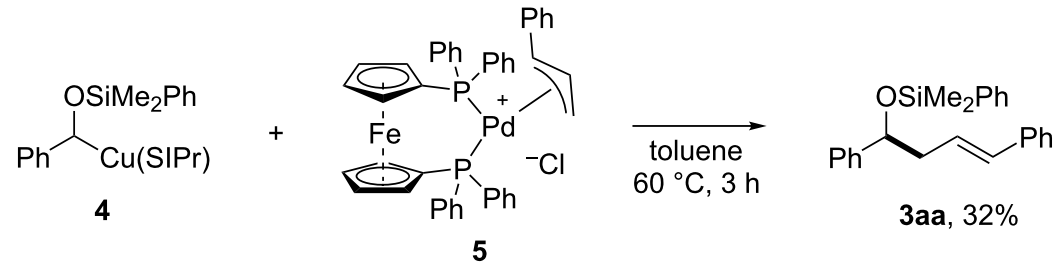

Scheme 4: Stoichiometric reaction.
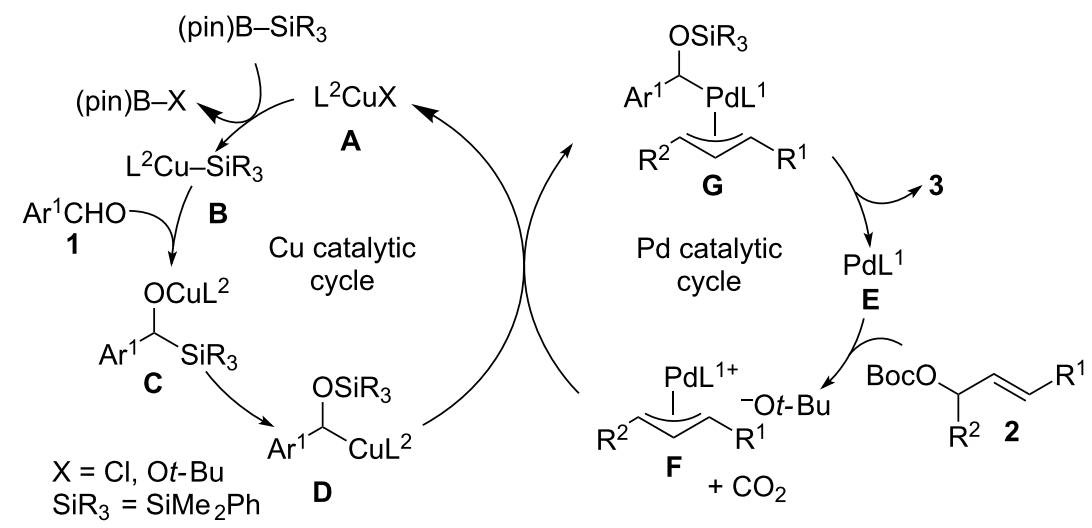

Scheme 5: Possible pathway. 
reductive elimination from $\mathbf{G}$ produces the homoallylic alcohol $\mathbf{3}$ and then regenerate $\mathbf{A}$ and $\mathbf{E}$ for the next catalytic cycle [2023].

\section{Conclusion}

In summary, we developed an umpolung strategy for catalytically formed $\alpha$-alkoxyalkyl anions from aromatic aldehydes for the use in allylic cross-coupling reactions. The synergistic palladium/copper-catalyzed reaction of aromatic aldehydes, allylic carbonates, and a silylboronate delivered the homoallylic alcohol derivatives. This process involves the catalytic formation of a nucleophilic $\alpha$-silyloxybenzylcopper(I) species and the subsequent palladium-catalyzed allylic substitution.

\section{Experimental}

$\mathrm{SIPrCuCl}$ (14.7 mg, $0.03 \mathrm{mmol}$ ), and $\mathrm{KO} t-\mathrm{Bu}(4.5 \mathrm{mg}$, $0.04 \mathrm{mmol}$ ) were placed in a vial containing a magnetic stirring bar. The vial was sealed with a Teflon ${ }^{\circledR}$-coated silicon rubber septum, and then the vial was evacuated and filled with nitrogen. Toluene $(0.6 \mathrm{~mL})$ was added to the vial, and then the mixture was stirred at $25{ }^{\circ} \mathrm{C}$ for $10 \mathrm{~min}$. Next, $\mathrm{PhMe}_{2} \mathrm{SiB}$ (pin) (104.9 mg, $0.4 \mathrm{mmol}$ ) and benzaldehyde (1a, $42.4 \mathrm{mg}$, $0.4 \mathrm{mmol}$ ) were added, and the mixture (mixture A) was stirred at $25{ }^{\circ} \mathrm{C}$ for $10 \mathrm{~min}$. Meanwhile, $\mathrm{Pd}\left(\mathrm{OCOCF}_{3}\right)_{2}(2.0 \mathrm{mg}$, $0.006 \mathrm{mmol}$ ) and DPPF (3.3 mg, $0.006 \mathrm{mmol}$ ) were placed in another vial. This vial was sealed with a Teflon ${ }^{\circledR}$-coated silicon rubber septum and then evacuated and filled with nitrogen. After toluene $(0.8 \mathrm{~mL})$ was added to the vial, the mixture was stirred at $25{ }^{\circ} \mathrm{C}$ for $10 \mathrm{~min}$. Next, $\mathrm{KOt}$-Bu ( $\left.1.1 \mathrm{mg}, 0.01 \mathrm{mmol}\right)$ and allylic carbonate $\mathbf{2 a}(46.9 \mathrm{mg}, 0.2 \mathrm{mmol})$ were added to the vial, and the mixture (mixture B) was stirred at $25^{\circ} \mathrm{C}$ for $10 \mathrm{~min}$. Finally, the palladium solution (mixture B) was transferred to the vial (mixture A) containing the copper complex with toluene $(0.6 \mathrm{~mL})$. After $12 \mathrm{~h}$ stirring at $80{ }^{\circ} \mathrm{C}$, the reaction mixture was diluted with diethyl ether $(1 \mathrm{~mL})$. The reaction mixture was filtered through a short plug of aluminum oxide $(1 \mathrm{~g})$ with diethyl ether as an eluent. After volatiles were removed under reduced pressure, GPC (EtOAc) followed by flash chromatography on silica gel (0-1\% EtOAc) hexane) gave product 3aa in $64 \%$ isolated yield $(45.7 \mathrm{mg}$, $0.13 \mathrm{mmol}$ ).

\section{Supporting Information}

\section{Supporting Information File 1}

Experimental procedures, spectroscopic and analytical data, and copies of NMR spectra for newly synthesized compounds.

[https://www.beilstein-journals.org/bjoc/content/ supplementary/1860-5397-16-21-S1.pdf]

\section{Funding}

This work was supported by JSPS KAKENHI Grant Number JP18H01971 to Scientific Research (B), JSPS KAKENHI Grant Number JP17H06449 (Hybrid Catalysis), and Kanazawa University SAKIGAKE project 2018 (to H.O.).

\section{ORCID ${ }^{\circledR}$ iDs}

Hirohisa Ohmiya - https://orcid.org/0000-0002-1374-1137

\section{References}

1. Hoppe, D.; Hense, T. Angew. Chem., Int. Ed. Engl. 1997, 36, 2282-2316. doi:10.1002/anie.199722821

2. Still, W. C. J. Am. Chem. Soc. 1978, 100, 1481-1487. doi:10.1021/ja00473a025

3. Papillon, J. P. N.; Taylor, R. J. K. Org. Lett. 2002, 4, 119-122. doi:10.1021/ol016986e

4. Linderman, R. J.; Godfrey, A.; Horne, K. Tetrahedron Lett. 1987, 28 , 3911-3914. doi:10.1016/s0040-4039(00)96418-9

5. Arai, N.; Suzuki, K.; Sugizaki, S.; Sorimachi, H.; Ohkuma, T. Angew. Chem., Int. Ed. 2008, 47, 1770-1773. doi:10.1002/anie.200704696

6. Laitar, D. S.; Tsui, E. Y.; Sadighi, J. P. J. Am. Chem. Soc. 2006, 128, 11036-11037. doi:10.1021/ja064019z

7. Takeda, M.; Yabushita, K.; Yasuda, S.; Ohmiya, H. Chem. Commun. 2018, 54, 6776-6779. doi:10.1039/c8cc01055b

8. Yabushita, K.; Yuasa, A.; Nagao, K.; Ohmiya, H. J. Am. Chem. Soc. 2019, 141, 113-117. doi:10.1021/jacs.8b11495

9. Takeda, M.; Mitsui, A.; Nagao, K.; Ohmiya, H. J. Am. Chem. Soc. 2019, 141, 3664-3669. doi:10.1021/jacs.8b13309

10. Nahra, F.; Macé, Y.; Lambin, D.; Riant, O. Angew. Chem., Int. Ed. 2013, 52, 3208-3212. doi:10.1002/anie.201208612

11. Jia, T.; Cao, P.; Wang, B.; Lou, Y.; Yin, X.; Wang, M.; Liao, J. J. Am. Chem. Soc. 2015, 137, 13760-13763. doi:10.1021/jacs.5b09146

12. Kim, I. S.; Ngai, M.-Y.; Krische, M. J. J. Am. Chem. Soc. 2008, 130, 6340-6341. doi:10.1021/ja802001b

13. Ketcham, J. M.; Shin, I.; Montgomery, T. P.; Krische, M. J. Angew. Chem., Int. Ed. 2014, 53, 9142-9150. doi:10.1002/anie.201403873

14. Denmark, S. E.; Matesich, Z. D. J. Org. Chem. 2014, 79, 5970-5986. doi:10.1021/j0501004j

15. Kleeberg, C.; Feldmann, E.; Hartmann, E.; Vyas, D. J.; Oestreich, M. Chem. - Eur. J. 2011, 17, 13538-13543. doi:10.1002/chem.201102367

16. Cirriez, V.; Rasson, C.; Hermant, T.; Petrignet, J.; Díaz Álvarez, J.; Robeyns, K.; Riant, O. Angew. Chem., Int. Ed. 2013, 52, 1785-1788. doi:10.1002/anie.201209020

17. Delvos, L. B.; Hensel, A.; Oestreich, M. Synthesis 2014, 46, 2957-2964. doi:10.1055/s-0034-1378542

18. Oestreich, M.; Hartmann, E.; Mewald, M. Chem. Rev. 2013, 113, 402-441. doi:10.1021/cr3003517

19. Hensel, A.; Oestreich, M. Asymmetric Addition of Boron and Silicon Nucleophiles. In Progress in Enantioselective Cu(I)-catalyzed Formation of Stereogenic Centers; Harutyunyan, S., Ed.; Top. Organomet. Chem., Vol. 58; Springer: Cham, Switzerland, 2016; pp 135-167. doi:10.1007/3418_2015_156

20. Pye, D. R.; Mankad, N. P. Chem. Sci. 2017, 8, 1705-1718. doi:10.1039/c6sc05556g 
21. Semba, K.; Nakao, Y. J. Am. Chem. Soc. 2014, 136, 7567-7570. doi:10.1021/ja5029556

22. Smith, K. B.; Logan, K. M.; You, W.; Brown, M. K. Chem. - Eur. J. 2014, 20, 12032-12036. doi:10.1002/chem.201404310

23. Friis, S. D.; Pirnot, M. T.; Buchwald, S. L. J. Am. Chem. Soc. 2016, 138, 8372-8375. doi:10.1021/jacs.6b04566

\section{License and Terms}

This is an Open Access article under the terms of the Creative Commons Attribution License

(https://creativecommons.org/licenses/by/4.0). Please note that the reuse, redistribution and reproduction in particular requires that the authors and source are credited.

The license is subject to the Beilstein Journal of Organic Chemistry terms and conditions:

(https://www.beilstein-journals.org/bjoc)

The definitive version of this article is the electronic one which can be found at: doi:10.3762/bjoc. 16.21 